\title{
Tourist guides and free tours: a controversial relationship
}

\begin{tabular}{|c|l|}
\hline Journal: & Tourist Studies \\
\hline Manuscript ID & TOU-20-0153.R1 \\
\hline Keywords: & $\begin{array}{l}\text { Tourist guide, collaborative consumption, tourist volunteering, free tour, } \\
\text { Freemium }\end{array}$ \\
\hline Abstract: & $\begin{array}{l}\text { Like other tourism subsectors, guided tours have been affected by the } \\
\text { emergence of the sharing economy. Although this subsector of tourism is } \\
\text { not as well known, it constitutes an interesting scenario for studying } \\
\text { these new business models and it is also generating debate. This article } \\
\text { analyses the uniqueness of the tourist guide services provided through } \\
\text { online platforms under the name of free tours. The study includes a } \\
\text { bibliographical revision and it is carried out from a qualitative } \\
\text { methodogy based on a survey conducted among tourist guide } \\
\text { professionals and in-depth interviews. The study analyse the point of } \\
\text { view of professional of guiding sector, to determine how they are } \\
\text { affected by the sharing economy and observe what their relationship } \\
\text { with this new activity is like, a complex relationship with many } \\
\text { controversial elements in terms of labour, tax and organization. It will be } \\
\text { shown that the free tours respond to the trends of contemporary society } \\
\text { but are not an expression of the collaborative consumption among } \\
\text { equals, but rather an effective marketing strategy. }\end{array}$ \\
\hline & \begin{tabular}{l} 
Oringl manuscript \\
\hline
\end{tabular} \\
\hline
\end{tabular}

\section{SCHOLARONE Manuscripts}




\title{
TOURIST GUIDES AND FREE TOURS: A CONTROVERSIAL RELATIONSHIP
}

\begin{abstract}
Like other tourism subsectors, guided tours have been affected by the emergence of the sharing economy. Although this subsector of tourism is not as well known, it constitutes an interesting scenario for studying these new business models and it is also generating debate. This article analyses the uniqueness of the tourist guide services provided through online platforms under the name of free tours. The study includes a bibliographical revision and it is carried out from a qualitative methodology based on a survey conducted among tourist guide professionals and indepth interviews. The study analyse the point of view of professional of guiding sector, to determine how they are affected by the sharing economy and observe what their relationship with this new activity is like, a complex relationship with many controversial elements in terms of labour, tax and organization. It will be shown that the free tours respond to the trends of contemporary society but are not an expression of the collaborative consumption among equals, but rather an effective marketing strategy.
\end{abstract}

\section{Keywords}

Tourist guide, collaborative consumption, tourist volunteering, free tour, Freemium. 


\section{Introduction}

Since the appearance of the Internet, there has been a development and expansion of activities related to the sharing economies and consumption that have been studied from different sectors (Botsman \& Roger, 2010, Belk, 2014a; Koopman et al., 2015). In tourism the increase has been motivated by the development experienced on an international level arising from the change in the economic paradigm based on use, access and enjoyment but not on ownership (Dervojeda et al, 2013); the prominence of the social networks, as they encourage interactions between peers (P2P) (Munar et al., 2013; Figuerola, 2016; Kuo et al., 2016); and the severe economic crisis that has fostered the development of new strategies and business models which generate complementary income for traditional companies (Gansky, 2010; Souto, 2015, Alaminos \& Penalva, 2018). Furthermore, changes may be observed in types of consumption and the behaviour of postmodern tourists, who seek experiences that go beyond banal activities and are attracted by authenticity and living alongside the residents (Dredge \& Gyimóthy, 2015). There has been an increase in the search for less expensive options observed (Meged \& Zillinger, 2018) either due to limited economic resources or to the desire to see more on the same budget.

The emergence of the sharing economy in different tourism subsectors, such as accommodation, transport, gastronomy, experiences and, even what we could call communication services (WiFi and roaming) (Guttentag, 2015; Díaz et al., 2016; Cesarini \& Nechita, 2017; Gutiérrez et al., 2017; Zervas et al., 2017) has generated controversy, due to the implementation of payment mechanisms in exchange for services which are developed in a different way, taking advantage of legal and administrative loopholes. This gives rise to the concept of the "pseudo-sharing economy" (Karlsson et al., 2017:3), which has features of the traditional economy, such as the maximisation of supply, but which is associated to a philosophy of sharing, the use of social networks and trust generated by peer contact (Botsman \& Rogers, 2010, Gansky, 2010, Meged \& Zillinger, 2018). This has aroused the interest of tourism researchers in the last decade (Erkus \& Eraydın, 2010; Belk, 2014b; Dredge \& Gyimóthy, 2015; Karlsoon et al., 2017; Brochado et al., 2017).

Researchers have highlighted the main challenges and opportunities of collaborative tourism related to aspects that range from the values that underlie this modality and that connect with the motivations and decision-making process of tourists (Alonso-Almeida et al., 2020), to the perception of the local population and the effects on businesses (Tussyadiah \& Sigala, 2017).

This generates a critical intellectual debate focused on the relationship between sharing 
economy firms and customers, and that addresses this phenomenon as a business model, hence aspects such as trust in platforms are analysed (Kim et al, 2018), the importance of rates (Gibbs et al, 2018; Liang et al, 2018), their impact on marketing strategies (Eckhardt et al., 2019). The controversy of the shared economy is also approached from the perspective that the shared economy creates new impacts on tourist destinations (Moreno-Gil \& Coca-Stefaniak, 2020) or exhausts existing ones, due to overtourism (Koens et al., 2018). It is understood that in many cases it is a model that is based on the co-option of market principles and the absence of regulation (Collier et al., 2018; Ahsan, 2020).

Even though the tourist guide presents interpretive keys similar to the rest of tourism activities the social and the academic interest aroused in the analysis of this activity has been scarce (Black et al., 2019), the most recent and relevant contributions being those of Zillinger et al. (2012); Weiler \& Black (2015) and Meger \& Zillinger, (2018). They focus their studies on the relationships between 1. Guide's relationship with the places they visit and their communities; 2. Its interaction with other activities and with tour operators; 3. Their interaction with consumers; 4. The incorporation of technology and 5. Its orientation to market niches. But the relationship of the tourist guide with the new formulas of collaborative economy and with the free tours are still scarce (Bryon, 2012; Zillinger et al., 2012; Navalón-García \& Mínguez, 2016; Leal \& Medina, 2018; Meged \& Zillinger, 2018). This opens a new field of research that must be addressed since this growing practice highlights some considerably important issues.

With this article we contribute to the literature with a revision of the scientific texts and the concepts related to the free tour phenomenon. This way, by identifying and presenting the different points of view so as to determine whether this activity is actually collaborative and of social value or simply a disguised business. Also this research seeks to determine the perception that the guides have of this new model, their relationship with it and the reasons for assessment of its impact on the profession.

For this purpose, the article is structured into five sections. After this introduction, the second part focuses on the principal conceptual and operational elements of these types of services and their evolution in relation to the sharing economy. Subsequently, the third section shows the sources and methods used in our research, highlighting the survey and the interviews. The fourth section introduces the results we obtained, and the fifth discusses them and presents the final conclusions of the research. 


\section{Regarding the free tours phenomenon \\ 2.1 The free tour guide service}

The reference texts on collaborative consumption by Botsman and Rogers (2010) and Gansky (2010) reveals the diversity of the fields in which this approach can be developed, including the provision of services linked to tourism. Going beyond product and re-distribution systems, basically focused on the possibility of sharing or exchanging material goods and knowledge, the central idea of this text is based on the service that connects people with common interests and, for the case in hand, those who share a similar concept of the travelling and tourist special experience with a local people.

From this perspective, collaborative consumption in tourism, and more specifically in free tours, constitutes a value for users, enabling them to develop connections with the destination and with the people residing therein, providing a richer and more authentic experience (Dredge \& Gyimóthy, 2015; Meged \& Kristensen, 2017) which leads him to travel and know the less known spaces (MacCannell, 2003).

Tourist guides form an essential piece of the tourism experience and are fundamental in the interface between the host destination and the visitors (Cohen, 1985; Ap \& Wong, 2001). Therefore, they must adapt to the global trends in demand and the circumstances of the context (Zillinger et al., 2012). There are different classifications of tourist guides (Bryron, 2012) according to the organisation formula, the target groups or the content that they offer and how they present it. Of these, the so-called relational guide is associated with the free tours, which have been proliferating for about a decade in the principal urban destinations of Europe and parts of America and Asia.

Free tours visits are given by people who, altruistically, provide a service to the visitors who request it. The initial premise is to provide a different experience to the traditional tours conducted by host volunteers who show the visitors places of interest and customs of the local life, in exchange for a tip "if the quality of service deserves one", as indicated at the end of each tour.

The combination of all of this has given rise to the free guided tours formula, which connects a tourist who is looking for a different style of tour with a more informal and cheerful guide. Operating from online platforms, they take advantage of the widespread use of technology and social networks and have established themselves as a new form of business with variable income that is earned through tips. Initially, the objective of the free tours is to foster a cultural 
exchange between equals, but, in practice, they are a commodification of the sharing economy. The emergence of these companies through platforms means that they can be considered as a disruptive activity (Yu \& Hang, 2010; Meged \& Zillinguer, 2018), drastically affecting the operations of the traditional tourist guide services where they set up.

The study of free tours connects several different current and interesting topics: 1) It reveals how the guided tours sector is adapting to the experience economy (Pine \& Gilmore, 1998) by offering a more emotive and interpersonal service provided by local people, based on a relationship between equals, which is typical of the sharing economy (Dredge \& Gyimóthy, 2015). 2) This type of service connects with the principles of host volunteering (Uriely et al., 2003; Lockstone-Binney et al., 2010a). The knowledge that these volunteers have of the place generates satisfaction and a positive perception which is spread through social networks by electronic word of mouth (Smith \& Holmes, 2012; Hanbeger, 2012). 3) We should also add that the administrative regulations of guided tour services are scarce and disperse and regulated by a continually evolving national and international legal framework (Pérez, 2013; Touloupa, 2010; Martínez, 2017).

\subsection{Precedents of collaborative consumption in guided tours}

Although the term "collaborative consumption" was not coined until the first decade of the $21^{\text {st }}$ century it is an activity which began to be developed in the tourism sector in different ways much before then. Especially, in relation to the guided tour services, it has long been known that spontaneous or "cicerone" tours also exist. These were conducted by volunteers in the surrounding areas of the most emblematic monuments of the traditional tourist destinations offered either frees of charge or, in the majority of cases, in exchange for tips. The quality of this type of tours, which has not been officially verified, has always been criticised by the licensed guides, defending their field of work and the solvency of the service provided. The main difference between free tours and "cicerone" ones is based on the fact that the objective of the activity is, above all, rooted in the motivation to share and not only in a desire to make money, although this cannot be dismissed.

In fact, the nature of these services can be related to volunteering activities in recreational environments, provided by hosts episodically or steadily (Holmes, 2014), for example, in museums, heritage sites, information centres, natural parks, at sports events or other occasions (Lockstone-Binney et al., 2010b). The reasons for this volunteering can be diverse depending on 
the age and personal situation of the individuals, but, in general, they are related to the sharing economy concept of a desire to share values and the idea that the exchange of knowledge implies a personal and social improvement (Holmes, 2014) which contributes to the common benefit and the improvement of the community in general. Volunteering and free tours share the common characteristics described by Handy et al. (2000): no formal link with the entity, the receipt of a reward, the existence of an organisational structure and the proximity to the beneficiaries. The voluntary relationships with the organisation can vary in strength, depending on prior expectations and the type of relationship in which both parties benefit. What seems clear is that there is a tendency to use volunteers or similar figures as a means to compensate the deficiencies in the hiring of services, in both the public and private sectors (Pick et al., 2011).

From a fundamentally altruistic point of view, the clearest precedent of this activity is set in 1992 in the city of New York, with the development of the Big Apple Greeter project. This initiative was developed around a group of non-professional volunteers who received no financial gain but had the desire to show visitors a more real, friendly and authentic city which was farremoved from the tourism clichés and, very close to the principles of collaboration and experience in contact with the local (Espeso et al., 2005). The Greeter organisation emerged with the objective of offering accompaniment and guided tours to visitors, conducted by volunteering New Yorkers free of charge and with no public or private economic support. Therefore, it kept its operating costs (mainly related to coordination) to a minimum, covered by donations or the participation of other companies which could benefit from an improved and more diverse image of the city (Holmes \& Smith, 2009). For its characteristics the greeter movement is the precedent that reflects the organisation principles of collaborative consumption in the guided tour sector, because, for the first time, work areas were established based on the new proposals: volunteerism, diffusion and informal financing for organising the structure.

\subsection{The free tour: between the sharing and experience economy}

Due to the fact that tourists want experiences (Pine \& Gilmore, 1998), the tour guide companies respond with the design and explicit promotion of proposals that invite participation and even immersion (Hansen \& Mossberg, 2017). It is a response of postmodern tourism that has transferred the economic value from products and goods to services and experiences, fulfilling its four dimensions: education, escapism, aesthetics and entertainment (Pine \& Gilmore, 1998). Free 
tours are products that promote a close relationship between those who give the guided service and their clients, through a style of communication and a context that invites an exchange. We can identify characteristics that are considered to be basic in the creation of the experience (Hansen \& Mossberg, 2017): 1) it is an active and dynamic process; 2) it has a strong social dimension; 3 ) there is interaction between the participants in a joyful and dynamic context; 4) the interaction generates knowledge; and 5) the process depends on a certain level of uncertainty associated with something new (expectations of fun and experiences are generated in the tours).

This cultural framework is combined with a population sensitive to economy issues, with an extensive digital literacy culture and a widespread presence of technology. This combination of factors fosters the emergence of proposals in the tourism sector related to collaborative consumption which can generate different benefits. First, objective advantages are obtained related to price, which is perceived as being lower, and can even be close to zero, which attracts new users to this type of consumption. Furthermore, this model is identified with other emotional advantages (Cañigueral, 2014) derived from participating in a system able to generate the feeling of mutual collaboration, a sense of belonging to a community or the feeling of acting intelligently in order to make a more efficient use of time and resources. Therefore, the free tour offer, which was initially aimed at young clients with a low purchasing power, has also captured the broader principal market of guided tours (Meged \& Zillinger, 2018; Leal \& Medina, 2017).

Within this context, the use of social networks in free tours acquires a relevant role, both in terms of their operation and communication and in setting an ideological context within which information is shared and a not-for-profit activity is carried out (Botsman \& Rogers, 2010; Gansky, 2010). The contact provided by technology between tourists and guides eliminates, or reduces, one of the weaknesses of the traditional institutionalised activity: the redundant intermediation (user-administration-company-guide), which is more complex and slower than a direct relationship (guide-user) which occurs with the free tours, offered simply and through websites or directly in the street.

\subsection{Elements for controversy}

The emergence of the free tours has stimulated innovation in three different areas: the way of acting, the relationship between the actors and the functioning of the organisations that cooperate and act in the space, so much so that we can refer to a disruptive process (Christensen, 2006). These changes have drastically affected the tourist guide service market and changed the rules of 
the game, for example, in terms of price, competition or organisation. These mutations can be observed in the following elements:

First, the use of the Internet and Web 2.0 facilitates the visibility of products, interaction and the exchange of knowledge between the agents involved and also free promotion through electronic word of mouth. It encourages potential visitors to contact the suppliers directly, based on recommendations of other users in the best positioned websites. In general terms, free tours are linked to powerful online marketing platforms and this generates tension between the competition and changes in the tourist guide services market (Hanberger, 2012; Bryon, 2012, Meged \& Zillinger, 2018).

These new ways of operating clash with the inertias of the tour guide sector, on the whole organised in professional associations which negotiate and contact the tourism administration of the destination (Navalón and Mínguez, 2016; Leal and Londoño, 2018; Meged \& Zillinger, 2018). To date, the administration-guide-user relationship has worked in a coordinated way based on collaboration patterns and mutual recognition. The traditional structure is characterised by the control of the administration, the associations and the predominance of small companies. This favours the control of the procedures and the way in which the service is provided; for example, establishing stipulated minimum prices in detriment to the user, or using mechanisms that limit the incorporation of new professional guides into the market in the form of permits or accreditations.

This relationship between the guides, the administration and the users has been affected by the emergence of the free tours which differ somewhat to the traditional model. On the one hand, given that there are no initial fixed prices, the visitors perceive the free tour model as a cheaper and fairer formula, as they decide the amount to tip at the end of the tour in accordance with the perceived quality. On the other hand, given the informal nature of the free tour, the guides can work without being officially accredited in some places, in accordance with the legislation of each destination (Meged \& Zillinger, 2018). In this respect, the Directive of the European Parliament and of the Council (123/2006/CE), colloquially known as Bolkestein, introduced changes, facilitating the free presentation of services in the internal market. Its application in different states and regions has generated different interpretations and regulations. This Directive has created a legal framework that legitimizes the conduct of guided tours by EU professionals in any member state, regardless of where they have obtained their license, provided they comply with the different accreditation and validation procedures. The issue was 
creating tension among professionals in the sector, until some countries requested the exemption from labour market liberation (Touloupa, 2010).

Consequently, considering the context of the economic and social change, it seems evident that the collaborative economy and the traditional tour guide companies are obliged to interact, although this is not easy. Friction arises from the perception of a new and powerful competitor that obliges them to change the way that they work. The following pages address the study of the perception of tour guide professionals of the free tour phenomenon.

\section{Objectives and methodology}

This research seeks to confirm whether the free tour phenomenon implies the real adaptation of this tourism sector to the new trends of the sharing economy or, on the contrary, whether it constitutes a new business strategy to capture clients. Furthermore it was attempted to demonstrate whether or not there is a competitive conflict between guides who are employed in the traditional manner and those who are involved in this new form of tours. In order to do this, the following premises will be addressed:

1. Whether the agents of the sector are adapting to the current trends of tourism demand with the proposal of new, creative and experiential models.

2. Whether the free tours is a pretext to establish initial contact and therefore offer other guided services under traditional parameters and guidelines.

3. If there is a difference between the tours which are conducted in the usual way and those of free tours.

4. Whether their relationship is conflictive or symbiotic and whether it causes impacts on the profession.

The activities carried out within the sharing economy receive media attention and generate a significant social impact. However, in this case, the opinion of the experts who directly participate in the activity is sought as they have the best knowledge about the reality affecting their professional development. Experts are considered those professionals of the guiding sector, whether they did free tours or not, without distinguishing between those how are licensed and those how are not. They have been contacted through guiding associations, which have distributed the questionnaire to its members. 
The study was conducted using fundamentally qualitative methods, considered the most appropriate given the exploratory nature of the study and the limited availability of information on this topic. For the first part of the study, closed-ended questionnaires online were distributed among the professional guides through the digital media. The survey was answered by 55 professionals, during the months of July, August and September 2018. They work in different European cities (Madrid, Barcelona, Valencia, Lisbon, Coimbra, Prague, Budapest, among others), because all operated in the EU and they are subject to the same normative framework. The consultation was directed to these professional guides, whether they did free tours or not.

The research did not focus on choosing a numerically representative sample, but on presenting different points of view of professionals from different places, experiences and cases (Jennings, 2005). These professionals were asked about different aspects of practising their profession, grouped into two blocks: 1) About the performance of the profession \& 2) About the perception of the free tour.

For the second part, the study is completed by ten in-depth interviews of professional guides who operate with free tours and traditional tours, in order to qualify and corroborate certain aspects, especially those linked to exercising the profession in different countries, with an emphasis on the freedom to practice and taxation. These professionals were asked about the relationship of collaboration or competition between the different types of guides; and if there are collaboration strategies between them. They were also asked about how they attract employees and customers, how payment is made, and how commission payments and tax benefits declarations are made. The interviews were conducted between the Spring and Summer of 2019. Of the ten guides that were interviewed three currently work in free tours, two others have collaborated occasionally with free tours and five work strictly as licensed guides.

In addition, the study was completed with an analysis of the five websites of the main entities that give free tours in European cities. Thus the characteristics of the tours that are offered have been compared in detail.

\section{Results}

\subsection{The exercising of the profession}

Most of the guides consulted have the administrative accreditation which authorises them to exercise the profession at sites declared as heritage of cultural interest. This can be carried out in many different ways, the free tour being one of them. Although some guides are exclusively 
engaged in providing these types of tours, there are also professionals who combine this with other activities such as being tourist guides for the municipal authorities or guides who work for their own companies or other companies.

"The majority of guides who take part in free tours activities wear their official credentials where they can be easily seen.” (Guide 1. Alicante)

Some professionals even work on a freelance and individual basis with no business structure. The results of the query reveal that those guides who exclusively work in the free tour sector are a minority. According to the answers, these are mainly young people with less than ten years of experience in the profession and many of them do not have any official accreditation.

In general terms, the participants of the study consider themselves to be free tour guides just when this is their only employment possibility. Those who combine it with other forms of guided tours do not feel identified with this practice or consider it occasional and irrelevant in their employment context, possibly as they have other more stable sources of income. From the interviews and comments, a certain level of embarrassment can be detected in those who have worked as a free tour guide and some admit to even omitting this work from their CV.

"So far there is little collaboration. Personally, I've been tempted to do free tour, I think they do a good job and put a lot of passion into what they do (...) but I haven't dared do it for fear of generating problems" (Guide 2. Valencia).

First, because they believe that this practice is reviled by the professionals in the sector and second, because they feel ashamed that their earnings from this activity are in the form of tips.

Free tour guides earn an average of $€ 150$ per tour in the high season and use specific platforms such as Trip4real, Vayable, TriperOne or Yuniqtrip to which they pay a fixed amount (usually 15\%) for each client. This payment is made in exchange for a promotional framework in the market and receiving formal backing which guarantees their professionalism, given that the platforms generate trust and security in the user. Furthermore, they offer a commitment to quality and supervision of the contents of the service before making it available to the public.

Most of the guides interviewed use a combination of different tools to promote their service and capture clients. The most common formula is that of a website (own or institutional) 
and the use of leaflets and social networks. The latter enable the generation of feedback between the agents and the clients and also between the users [Table 1].

Table 1. Summary of the questionnaire conducted among tourist guides (\%)

\begin{tabular}{|c|c|c|c|c|c|c|c|c|c|}
\hline & \multirow[b]{2}{*}{$\begin{array}{l}\text { Leaflet } \\
\qquad \mathrm{s}\end{array}$} & \multirow{2}{*}{$\begin{array}{c}\text { Social } \\
\text { networ } \\
\text { ks }\end{array}$} & \multicolumn{3}{|c|}{ Websites } & \multicolumn{3}{|c|}{ Combined formulas } & \multirow{2}{*}{$\begin{array}{c}\text { Nothi } \\
\text { ng }\end{array}$} \\
\hline & & & $\begin{array}{l}\text { Platfo } \\
\text { rm } \\
\text { free } \\
\text { tour }\end{array}$ & $\begin{array}{c}\text { Institut } \\
\text { ional }\end{array}$ & Own & $\begin{array}{c}\text { Web } \\
\text { site+ } \\
\text { Leaf } \\
\text { lets }\end{array}$ & $\begin{array}{c}\text { Website + } \\
\text { Social } \\
\text { networks }\end{array}$ & $\begin{array}{c}\text { Website + } \\
\text { Leaflets + } \\
\text { Social } \\
\text { networks }\end{array}$ & \\
\hline Works only for free tour platform & & & 1.9 & & & & & 3.8 & \\
\hline $\begin{array}{l}\text { Local guide hired by municipal } \\
\text { bodies (self-employed) }\end{array}$ & & 9.6 & & 1.9 & 1.9 & 1.9 & 9.6 & 1.9 & 5.8 \\
\hline Owner of own business & & 1.9 & & & 11.5 & & 7.7 & 13.5 & 1.9 \\
\hline Works for another company & 1.9 & 1.9 & & 1.9 & 1.9 & & & 7.7 & \\
\hline Overall total & 1.9 & 13.5 & 1.9 & 3.8 & 15.4 & 1.9 & 17.3 & 26.9 & \\
\hline
\end{tabular}

Source: Own elaboration based on the data of the survey

The guides consider themselves to be a very collaborative group and highlight the importance of networking, to the point that they acknowledge that some of their clients are facilitated by other colleagues in the same company or even other companies. The relationship of trust between colleagues is noteworthy. They do not regard each other as competitors and hold great respect for the person who provides them with contacts.

"On some occasions, companies that advertise as free Tours have hired our services (certified guides) for private groups when necessary." (Guide 1. Alicante)

When comparing the way in which the guided tours are carried out, whether through companies, the local administration or free tour services, large differences cannot be observed. There are obvious similarities with respect to the size of the groups (average of 20 people), the origin of the clients (the majority claim that more than $75 \%$ of their clients are foreign tourists), the ages of the group (the majority are over 31 years of age) and even the amount earned per client (between 8 and 10 euros), irrespective of how the guided tour service is organised.

These results contrast with the theories that attribute differentiated characteristics to the users of the sharing economy (Meged \& Zillinger, 2018). The first of these unsubstantiated attributes is that these consumers are young people belonging to the millennial generation. The second 
unproven fact is that in a highly competitive context, the emergence of organisation formulas of collaborative consumption foster the creation of initiatives of volunteers who wish to conduct guided tours and provide special tourist services. Therefore, according to the survey, no large contrasts or drastic changes in the way in which the service is offered and received can be observed. Although there has been a common response that the differentiating element between these forms of service could be the use of a more informal communication style in the case of free tours.

\begin{abstract}
"The client who takes a free tour repeats in another city. And, that's because the style is different, the way of communicating, the things that are told, the informal tone and the closeness." (Guide 4. Prague)
\end{abstract}

The principal differences found between the two types of guidance are related to rates and the philosophy of the service and consumption. The flexibility to join the group and to leave it, forces free guides to work in a different way so that the group remains engaged which is essential since payment is handled at the end. In addition, while in traditional tours the price is established a priori, in the free tours the payment of the service is made through voluntary tips and, therefore is variable; although the amounts earned, as previously indicated, are almost identical. The most relevant aspect is that the service in the free tours is characterised by voluntary payment, while in the normal visits there is a fixed price and the tourists know what they are going to pay for the service when they hire it. In this way, the taxation of the work carried out in paid guided tour services is clearer. This issue is more complex and opaque in the case of the free tours.

\begin{abstract}
"Usually, the greater the effort a Free Tour guide makes, the more money they will earn. Other contributing factors include if they have pictures to show, if they use technology and if they take the adequate time to answer their clients' questions." (Guide 5. Alicante)
\end{abstract}

\title{
4.2 The perception of free tours
}

It is relevant that although the guides interviewed worked for free tour companies, they do not consider themselves as free tour guides. This shows that their opinion as professionals is realistic, but this subjective positioning also reveals that they are critical of the activity. In general terms, these types of tour are perceived as unfair competition (32\%), assuming that the people who 
conduct them do not always have the official accreditation, although is not a mandatory requirement for offering their services on online platforms.

"I have worked in Budapest with the Spanish clearance. Now I'm in Portugal, and here it's not required (...) but in my company, $80 \%$ of the guides are official." (Guide 6. Lisbon)

Almost all of the guides consulted have the official accreditation and their hiring and the payment of taxes are regulated which is not always the case for the free tour guides. In this respect, most of the licensed guides question the quality of the information given by the free tours and even claim that they provide a poor, limited and unprofessional service. However, a minority of them, $(7.3 \%)$ consider that they better adapt to the demand and that they offer better experiences than the traditional tours, enabling visitors to learn about the destinations in a different way. [Figure 1]

Figure 1. Controversial elements with respect to the practice of free tours $(\%)$

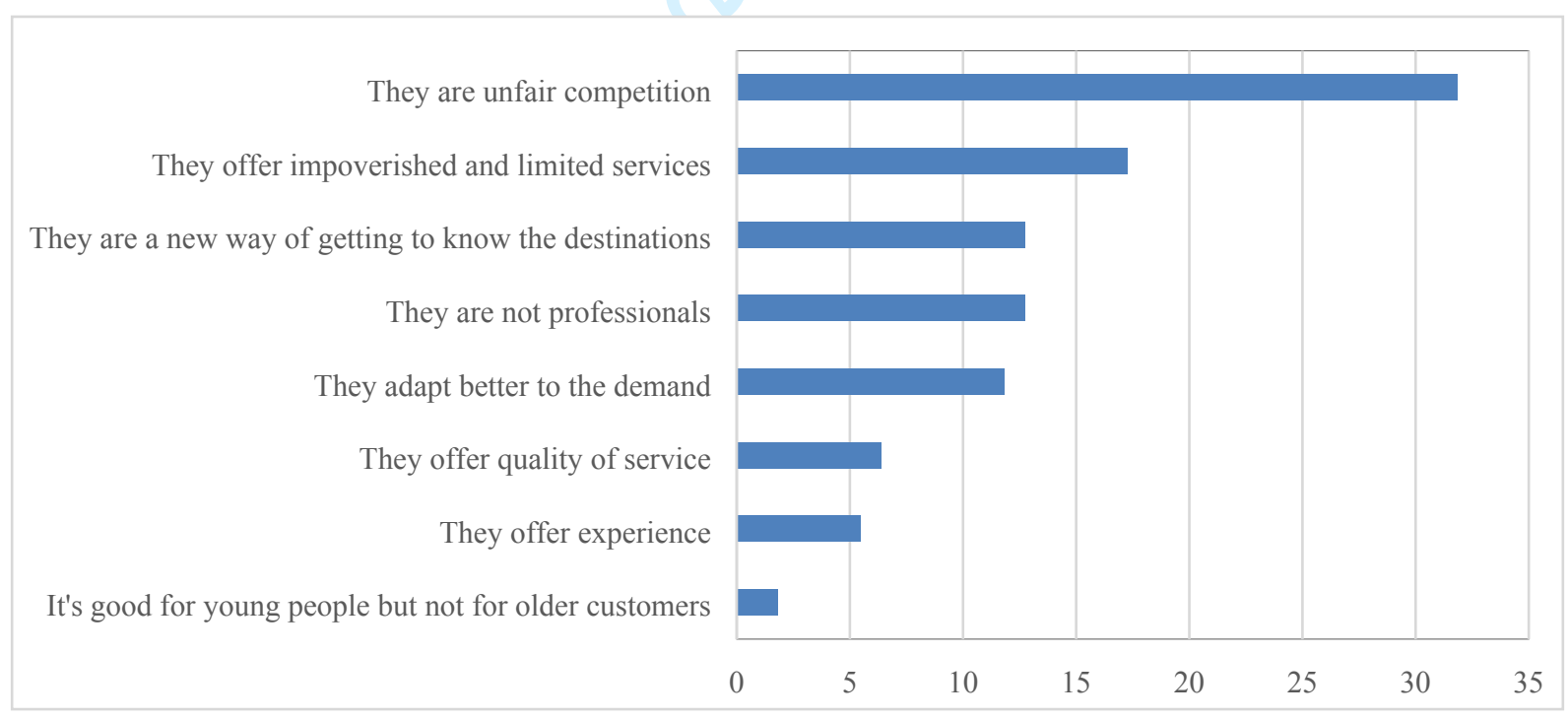

Source: Own elaboration based on the data of the survey

In relation to the previously mentioned points, particularly the differences regarding the legal and taxation requirements, the tourist guides consider that the emergence of the free tour phenomenon is the source of considerable conflict between professionals. They point out that this new model denigrates the profession, favours the infiltration of unauthorised or unqualified workers and undermines their social rights and recognition as professionals for which they have worked so hard to achieve. Furthermore, they believe that it is a practice that introduces and 
promotes the informal economy. They consider that it is fair to regulate the prices of the services in order to prevent unfair competition and to achieve a level of wages and rights similar to those of other professions.

"The system is not sustainable from the point of view of work, you can earn a lot of money as a free tour guide, but you are completely unprotected in every way." (Guide 8. Coimbra)

They also feel that these guides and platforms should offer a concise and clear service proposal from the beginning for the good of the clients. There is a degree of distrust with respect to whether the free tour guides work for tips (sometimes referred to as alms) and the majority highlight the problems derived from the opacity of the overall remuneration received and the obligation to pay taxes for the activity.

An important part of the criticism is rooted in the fact that the free tour platforms capture clients, initially attracted by the promise of a free service, and then offer other lucrative activities such as themed tours or routes for closed groups, which generate the most profit for the business. This reduces the capacity of the traditional suppliers to compete in the market and this is one of the key elements of the confrontation.

The idea of conflict is not only expressed by the certified guides but is also shared by those who operate as free tour guides $(78.9 \%$ of responses). These point out that they are not understood and that their work is not respected by their colleagues. They indicate that sometimes they are even verbally harassed in front of their clients. They feel upset because the accuracy of their information is questioned and they are accused of being illegal, when they are actually not undertaking any activity which is not allowed by law. In this respect, they effusively underline the fact that, partly due to the European directive, the profession is currently de facto liberalised and therefore their activity may be considered to be legitimate.

A minority of the respondents $(15.4 \%)$ consider that there is connivance or collaboration between the free tours and the licensed guides. Generally speaking, these responses coincide with guides who work as free tour guides full or part time and who are the same as those who in the previous question valued this activity as a good alternative with respect to offering new experiences and ways of getting to know a destination. [Figure 2 near here] 
Figure 2. Perception of the relationship between traditional and free tours (\%)

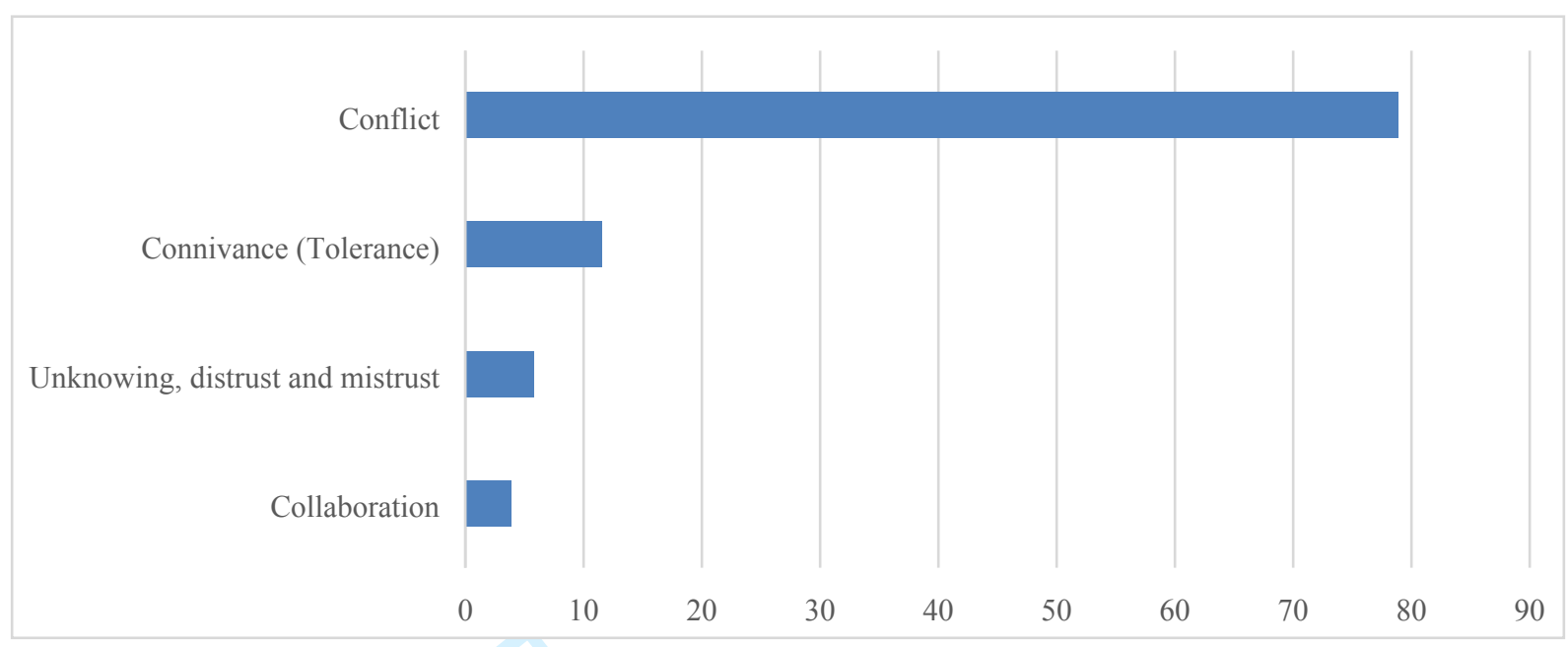

Source: Own elaboration based on the data of the survey

All these opinions reinforce the debate about the necessary regulation of the free tour platforms called for by the traditional professional companies and associations. For some, this economic exchange does not correspond to a collaborative consumption; however, this argument has been the driver of many of these types of platform.

\section{Discussion}

Every day, free tours are offered as a solidarity-based, fair activity comprising the coexistence of residents and visitors in accordance with the new models of the so-called sharing economy. Taking into consideration the responses of those surveyed and interviewed regarding the analysis of the demand, the composition of the groups and the routes that were done, the results of the survey and the interviews reveal that this activity is very similar to the usual guided tour service activities.

Although the free tours are considered as an altruistic and even free activity, in reality they are a type of cheap product subject to a variable price which represents a promotional lure for the supply of other traditional proposals. Therefore, the free tour platforms, in the same way as those dedicated to transportation or tourist accommodation, use this argument in order to attract demand and increase their economic profits (Meged \& Zillinger, 2018; Collier et al, 2018; Kumar et al, 2018). These are exclusively based on putting users and guides into contact with one another with no investment in any goods, services or product design (Cañigueral, 2019). 
It is a growing trend, precisely because it has such a positive image. For this reason, the companies use this altruist rhetoric, although only partially, in order to appear attractive in a changing market, where client rotation and service providers is high (Kumar et al, 2018). This is the case of some of the guided tour agencies and tour operators, such as Sandemans, Feel the city, Ogotours, Freewalkingtour, Guruwalk, among others, which offer free tours. Under this name, they offer high quality guided tours on foot for any person and any travel budget. In these cases, the idea of sharing experiences in a different way is the central focus of the advertising, although this attraction is only one part of the proposal as the key to the offer is fundamentally profit based, in the same way as other services.

Most of the supply of free tours can be found on large online platforms that offer a diverse portfolio of services, free tour or paid, which really make up the largest percentage. The formation of the groups and the characteristics of the users of the free tours are very similar to those of the users of traditional tours. In addition, it can be said that many of these online platforms operate in the same way as traditional companies in the sector, offering tours with similar characteristics and including the same star attractions of the locations. These basic tours are complemented with the offer of other options with differentiated features, which, in this case, have a controlled price. Therefore, the free tours adopt a Freemium business model (Pujol, 2010).

The principal difference with respect to other collaborative consumption platforms resides in the fact that these are guided tour companies that recruit freelance or contract workers who have an appropriate professional profile, who are extrovert and passionate about heritage and wish to work with a younger and more open demand In this case, following management patterns similar to those mentioned for the sharing economy platforms, they take on guides who request to be signed up as voluntary collaborators of the company (Zillinger et al. 2012). But they don't develop personalized tours for a client in a peer relationship, they just make the guided tour proposals that the company designs and promotes. This is because the standardisation of services facilitates management and minimises any possible incidents derived from diversity. Despite this, the marketing of these proposals targets a different type of demand, offering an informal rhetoric and seeking to promote different experiences.

The affiliation of these guides, (freelance or contract workers), to online platforms in exchange for a percentage of the income earned through the tips received cannot be associated considered a part of the sharing economy, even though that is the image they try to convey. The business definition and its approach do not have the same structure of delegated and shared responsibility as collaborative consumption platforms. The differential factor of these guided tour 
companies with respect to other traditional agencies resides in the fact that their portfolio of products includes certain tours that are offered free of charge for anyone (Meged \& Zillinguer, 2018). For these tours, the guides only receive tips from the users depending on the perceived quality and a percentage of these tips is given to the reference company. This the most controversial aspect of these types of business proposals between the agents involved in the sector, as the tax declaration of the tips and random income subject to the assessment of the clients is evidently not transparent.

Interestingly, many of the people interviewed do not indicate that the same problems of fiscal opacity found in the free tour platforms can occur in the traditional guided tour sector, possibly because they are all legally registered and pay their taxes as self-employed workers. The fact that the collaborative consumption platforms receive a percentage from the private guides who can charge for their services is not perceived as a topic for debate, provided that this is managed transparently to guarantee the legality and the good quality of the experience.

The leaflets and social networks influence the perception and assessment of the destinations and services and also help tourists make decisions (Miguéns et al., 2008). Tourists value very highly the ability to express their opinion (Goldsmith \& Horowitz, 2006) and obtain information from sources other than tourism companies (Schindler \& Bickart, 2012). The fact that those who provide this information are people similar to themselves offers them greater security and trust. However, they do not realise that free Tour guides actively encourage social media activity and request favourable reviews given that, on occasion, their earnings are directly tied to positive comments on the online search engines.

Another point of contention is the low quality attributed to the guides who give the free tours. They are reproached for their lack of professionalism, low-quality content, and, most of all, not being officially authorised to practice the profession. However, many accredited guides who were interviewed collaborate, or have done occasionally, with companies operating under the free tour formula. All of this indicates that there is a propensity for confrontation between the two groups and a superficial approach to the real element of confrontation: maintaining the market prominence of guided tours in tourist destinations.

\section{Conclusions}

From the results of the research it can be observed that free tours are not experiences of collaboration between peers, but a provision of a service in exchange for a discretional and 
irregular economic amount which depends on the disposition of the demand. Therefore, although some tours are offered free of charge, a payment for the service is always established albeit through tips, which constitutes a relatively regular amount, to the extent that the revenue from the free tours is similar to that of the traditional tours.

Thus, it appears that no major changes have been made in the supply of guided urban routes to indicate an adaptation to the new trends of demand with creative and experiential offers. The only real change is the fact that in order to operate free tours young and informal guides may be recruited who do not necessarily have to have the official accreditation for working in the profession. This leads to the free tour guides being perceived a priori by professionals as being of a lower quality but by the users as being more attractive.

The controversy generated between the free tour and professional guides is based on the perception of a situation of unfair competition. This is essentially due to three basic ideas: the first is that the so-called free tours are not really free and act as bait for offering other traditional products. The objective, therefore, is to capture the attention of the demand rather than to offer a different service. The second is the opacity of the revenue earned, as this is based on voluntary tips. Therefore, there is a situation of voluntary collaboration with a variable amount which makes fiscal control difficult. Although the earnings are not transparent, according to the individuals interviewed in the survey, the free tour guides were working in the profession legally as self-employed or contract workers who paid taxes on the revenue earned. The third idea is that the free tour guides do not require official accreditation, which gives rise to the questioning of their professionalism. But in many cases this procedure is fulfilled or is not necessary for the places where the routes are carried out.

It may be considered, therefore, that the free tour phenomenon does not imply the real adaptation of the tourism sector to the new trends of the sharing economy, but constitutes a new business strategy for capturing the demand more simply in a competitive environment.

Lastly, it should be highlight that the study provided new challenges and opened up new lines of research. These can further study how free tours are perceived from various perspectives, such as demand and other stakeholder involved in tourism management and development.

\section{References}

Ahsan, M. (2020). Entrepreneurship and ethics in the sharing economy: A critical perspective. Journal of Business Ethics, 161(1), 19-33. 
Alaminos, A. \& Penalva, C. (2018). Economía colaborativa: definiciones y escenarios. Sociologiados. Revista de Investigación Social, 3(1), 15-36.

Alonso-Almeida, M.; Perramon, J. Bagur-Femenías, LL. (2020): Shedding light on sharing Economy and new materialist consumption: An empirical approach. Journal of Retailing and Consumer Services. Vol 52.

Ap, J. \& Wong, K. (2001). Case study on tour guiding: professionalism, issues and problems. Tourism Management, 22 (5), 551-563. DOI: 10.14198/socdos.2018.3.1.01

Belk, R. (2014a). You are what you can access: Sharing and collaborative consumption online. Journal of Business Research, 67, 1595-1600. DOI: 10.1080/09720073.2014.11891518

Belk, R. (2014b). Sharing Versus Pseudo-Sharing in Web 2.0. The Anthropologist, 18(1), 7-23 DOI: $10.1080 / 09720073.2014 .11891518$

Botsman, R. and Rogers, R. (2010). What's mine is yours. The Rise of Collaborative Consumption. New York: Harper Collins.

Black, R., Weiler, B. and Chen, H. (2019). Exploring theoretical engagement in empirical tour guiding research and scholarship 1980-2016: a critical review. Scandinavian Journal of Hospitality and Tourism, 19(1), 95-113. DOI: 10.1080/15022250.2018.1493396

Bryon, J. (2012). Tour Guides as Storytellers - From Selling to Sharing. Scandinavian Journal of Hospitality and Tourism, 12(1), 27-43. DOI: 10.1080/15022250.2012.656922

Brochado, A., Troilo, M. \& Shah, A. (2017). Airbnb customer experience: Evidence of convergence across three countries. Annals of Tourism Research, 63, 210-212. DOI: 10.1016/j.annals.2017.01.001

Cañigueral, A. (2014). Vivir mejor con menos. Descubre las ventajas de la nueva economía colaborativa. Barcelona: Ed. Conecta.

Cañigueral, A. (2019). Hacia una economía de plataformas responsable. Cuadernos económicos de ICE, 97, 9-33.

Cesarini, M. \& Nechita, F. (2017). Tourism and the Sharing Economy. An evidence from Airbnb Usare in Italy and Romania, Symphonya. Emerging Issues in Management, 3, 3247. DOI: 10.4468/2017.3.04cesarani.nechita

Cohen, E. (1985). The tourist guide: The origins, structure and dynamics of a role. Annals of Tourism Research, 12, 5-29. DOI: 10.1016/0160-7383(85)90037-4

Collier, R. B., Dubal, V. B., \& Carter, C. L. (2018). Disrupting regulation, regulating disruption: The politics of Uber in the United States. Perspectives on Politics, 16(4), 919-937. 
Christensen, C.M. (2006). The Ongoing process of Building a Theory of Disruption. The Journal of Product Innovation Management, 23, 39-55. DOI: 10.1111/j.1540-5885.2005.00180.x

Dervojeda, K., Verzijl, D., Nagtegaal, F., Lengton, M., Rouwmaat, E., Netherlands, PwC Netherlands, Monfardini, E., Laurent Frideres and PwC Luxembourg (2013). The Sharing Economy Accessibility Based Business Models for Peer-to-Peer Markets Business Innovation Observatory. Case Study, 12. Report, European Union.

Díaz Armas, R., Gutiérrez Taño, D. \& García Rodríguez, F. (2016). ¿Por qué Airbnb es un modelo de alojamiento colaborativo con tanto éxito?, In J.A. Mondéjar \& E. Parra (dir). La actividad turística española en 2014. (pp. 111-118). Madrid: Ed: Síntesis y AECIT.

Dredge, D. \& Gyimóthy, S. (2015). The collaborative economy and tourism: Critical perspectives, questionable claims and silenced voices. Tourism Recreation Research, 40 (3), 286-302. DOI: 10.1080/02508281.2015.1086076

Eckhardt, G.; Houston, M.B.; Jiang, B.; Cait Lamberton, C.; Rindfleisch, A. and Zervas, G. (2019). Marketing in the Sharing Economy. Journal of Marketing, 1-23.

Erkus Öztürk, H. \& Eraydın, A. (2010). Environmental governance for sustainable tourism development: Collaborative networks and organization building in the Antalya tourism region. Tourism Management, 31, 113-124. DOI: 10.1016/j.tourman.2009.01.002

Espeso, P., Florescu, F., Grant, T. \& Haridasani, N. (2005). Big Apple Greeter Visitor Survey. Otium Consulting Group. New York: New York University.

European Council (2006). Directive 2006/123/EC of the European Parliament and of the Council of 12 December 2006 on services in the internal market. Available at: https:/eurlex.europa.eu/eli/dir/2006/123/oj (accessed 22 may 2020).

Figuerola Palomo, M. (2016). 2014, el año de la explosión de la economía colaborativa. Causas y situación actual. In J.A. Mondéjar \& E. Parra (dir) La actividad turística española en 2014. (pp. 101-109). Madrid: Ed. Síntesis y AECIT.

Gansky, L. (2010). The Mesh: Why the Future of Business is Sharing. New York: Penguin.

Gibbs, C., Guttentag, D., Gretzel, U., Morton, J. \& Goodwill, A. (2018). Pricing in the sharing economy: a hedonic pricing model applied to Airbnb listings. Journal of Travel \& Tourism Marketing, 35(1), 46-56.

Goldsmith, R.E. \& Horowitz, D. (2006). Measuring motivations for Online Opinion Seeking. Journal of Interactive Advertising, 6(2), 2-14. DOI: 10.1080/15252019.2006.10722114 
Guttentag, D. (2015). Airbnb: disruptive innovation and the rise of an informal tourism accommodation sector. Current Issues in Tourism, 18(12), 1192-1217. DOI: $10.1080 / 13683500.2013 .827159$

Gutiérrez, J., García-Palomares, J.C., Romanillos, G. \& Salas-Olmedo, M.H. (2017). The eruption of Airbnb in tourist cities: comparing spatial patterns hotels and Peert-to-peer accommodation in Barcelona. Tourism Management, 62, 278-291. DOI: 10.1016/j.tourman.2017.05.003

Hanbeger, K. (2012). Online communication within host volunteer tourism. The case of the Global Greeter network. Master's thesis, Götebourgs Universitet, SWE.

Handy, F., Cnaan, R.A., Brudney, J.L., Ascoli, U., Meijs, L.C. \& Ranade, S. (2000). Public Perception of "Who is a Volunteer": An Examination of the Net-cost Approach from a Cross-Cultural Perspective. Voluntas: International Journal of Voluntary and Nonprofit Organizations, 11(1), 45-65.

Hansen, A.H. \& Mossberg, L. (2017). Tour guides' performance and tourists' immersion: facilitating consumer immersion by performing a guide plus role. Scandinavian Journal of Hospitality and Tourism, 17(3), 259-278. DOI: 10.1080/15022250.2016.1162347

Holmes, K. (2014). It fitted in with our lifestyle': an investigation into episodic volunteering in the tourism sector. Annals of Leisure Research, 17(4), 443-459. DOI:10.1080/11745398.2014.965183

Holmes, K. \& Smith, K.A. (2009). Managing volunteers in tourism: attractions destinations and events. Oxford: Elsevier.

Jennings, G. R. (2005). Interviewing: a Focus on Qualitative Techniques. In B.W Ritchie, P. Burns, \& C. Palmer (Eds.), Tourism Research Methods: Integrating Theory with Practice (pp. 99-117). Wallingford/Cambridge: CABI.

Karlsson, L., Kemperman, A. \& Dolnicar, S. (2017). May I sleep in your bed? Getting permission to book. Annals of Tourism Research, 62, 1-12. DOI: $10.1016 /$ j.annals.2016.10.002

Kim, S., Lee, K. Y., Koo, C., \& Yang, S. B. (2018). Examining the influencing factors of intention to share accommodations in online hospitality exchange networks. Journal of Travel \& Tourism Marketing, 35(1), 16-31.

Koens, K.; Postma, A. \& Papp, B. (2018). Is Overtourism Overused? Understanding the Impact of Tourism in a City Context. Sustainability, 10, 4384. 
Koopman, C., Mitchell, M. \& Thierer, A. (2015). The Sharing Economy and Consumer Protection Regulation: The Case for Policy Change. The Journal of Business, Entrepreneurship \& the Law, 8(2), 529-545.

Kumar, V., Lahiri, A., \& Dogan, O. B. (2018). A strategic framework for a profitable business model in the sharing economy. Industrial Marketing Management, 69, 147-160.

Kuo, N.T., Chang, K.C., Cheng, Y.S. \& Lin, J.C. (2016). Effects of Tour Guide Interpretation and Tourist Satisfaction on Destination Loyalty in Taiwan's Kinmen Battlefield Tourism: Perceived Playfulness and Perceived Flow as Moderators. Journal of Travel \& Tourism Marketing, 33(1), 103-122. DOI: 10.1080/10548408.2015.1008670

Leal Londoño, M.P \& Medina, F.X. (2017). Free walking tour enterprises in Europe: An evolutionary economic approach. In D. Dredge \& S. Gyimóthy (eds). Tourism and collaborative consumption. Perspectives, politics, policies and prospects. (pp. 129-151). Berlin: Springer.

Liang, L. J., Choi, H. C., \& Joppe, M. (2018). Understanding repurchase intention of Airbnb consumers: perceived authenticity, electronic word-of-mouth, and price sensitivity. Journal of Travel \& Tourism Marketing, 35(1), 73-89.

Leal Londoño, M.P. \& Medina, X. (2018). Turismo y economía colaborativa: el caso de los recorridos gratuitos a pie en Barcelona. Cuadernos de Turismo, 41, 323-341. DOI: https://doi.org/10.6018/turismo.41.327051

Lockstone-Binney, L., Holmes, K., Smith, K. \& Baum, T. (2010a). Volunteers and volunteering in leisure: social science perspectives. Leisure Studies 29(4), 435-455. DOI: $10.1080 / 02614367.2010 .527357$

Lockstone-Binney, L., Smith, K. \& Baum, T. (2010b). Volunteering flexibility across the tourism sector. Managing Leisure, 15(1-2), 111-127. DOI: 10.1080/13606710903448202

MacCannell, D. (2003). El turista: una nueva teoría de la clase ociosa. Barcelona: Melusina.

Martínez Mata, Y. (2017). Bolkestein revisited in the era of the sharing economy. Revista Electrónica de Estudios Internacionales, 33, 1-19. DOI: 10.17103/reei.33.09

Meged, J.W. \& Kristensen, M.D. (2017). Working within the collaborative tourist economy: The complex crafting of work and meaning. In D. Dredge \& S. Gyimóthy (eds) Tourism and collaborative consumption. Perspectives, politics, policies and prospects. (pp. 203-220). Berlin: Springer. 
Meged, J.W. \& Zillinger, M. (2018). Disruptive network innovation in free guided tours. Scandinavian Journal of Hospitality and Tourism, 18(3), 303-318. DOI: $10.1080 / 15022250.2018 .1497317$

Miguéns, J., Baggio, R. \& Costa, C. (2008). Social media and Tourism Destinations: TripAdvisor Case. Advances in Tourism Research, 26(28), 1-6.

Moreno-Gil, S. \& Coca-Stefaniak, J.A. (2020): Overtourism and the sharing economy- tourism cities at a crossroads. International Journal of Tourism Cities, 6 (1), 1-7.

Munar, A., Gyimóthy, S. \& Cai, L. (2013) Tourism Social Media: A New Research Agenda. In Munar A, Gyimóthy S and Cai L (eds) Tourism Social Media: Transformations in Identity, Community and Culture. (pp. 1-15). Bingley: Emerald Group Publishing Limited.

Navalón-García, R. \& Mínguez García, M.C. (2016). El desarrollo del fenómeno de los tours gratuitos (free tours) en los destinos culturales. El caso de la ciudad de Madrid: colaboración o negocio. In M. Blàzquez, M. Mir-Gual, I. Murray I G.X. Pons (eds) Turismo y crisis. Turismo colaborativo y ecoturismo. (pp. 265-279). Palma de Mallorca: SHNB-UIB-AGE.

Pérez Fernández, J.M. (2013). Directiva de servicios y turismo: el nuevo régimen de acceso y prestación de los servicios turísticos y su contribución al incremento de la calidad turística. Revista de Derecho de la Unión Europea, 1(24), 257-318.

Pick, D., Holmes, K, \& Brueckner, M. (2011). Governmentalities of Volunteering: A Study of Regional Western Australia. Voluntas: International Journal of Voluntary and Nonprofit Organizations, 22(3), 390-408. DOI:10.1007/s11266-010-9161-5.

Pine, B.J. \& Gilmore, J.H. (1998). Welcome to the experience economy. Harvard Business Review, 76(4), 97-105.

Pujol, N. (2010). Freemium: attributes of an emerging business model. Available at SSRN 1718663. DOI:10.2139/ssrn.1718663

Schindler, R.M. \& Bickart, B. (2012). Perceived helpfulness of online consumer reviews: The role of message content and style. Journal of Consumer Behaviour, 11, 234-243. DOI: $10.1002 / \mathrm{cb} .1372$

Smith, K. \& Holmes, K. (2012). Visitor centre staffing: Involving volunteers. Tourism Management, 33(3), 562-568. DOI 10.1016/j.tourman.2011.06.010

Souto, J.E. (2015). Business model innovation and business concept innovation as the context of incremental innovation and radical innovation. Tourism Management, 51, 142 -155. DOI: 10.1016/j.tourman.2015.05.017 
Touloupa, S. (2010). Casting Identity in the Cultural Tourism Industry: Greek Tourist Guides in a 'Mission' of Heritage Interpretation. Public Archaeology, 9(1), 4-33. DOI: $10.1179 / 175355310 X 12657988535506$

Tussyadiah, I.P. \& Sigala, M. (2018). Shareable tourism: tourism marketing in the sharing economy, Journal of Travel \& Tourism Marketing, 35:1, 14, DOI: 10.1080/10548408.2018.1410938

Uriely, N., Reichel, A. \& Ron, A. (2003). Volunteering in Tourism: Additional Thinking. Tourism Recreation Research, 28(3), 57-62. RO: 10.1080/02508281.2003.11081417

Weiler, B. \& Black, R. (2015). Tour guiding research: Insights, issues and implications. Bristol: Channel View Publications.

Yu, D. \& Hang, C.C. (2010). A Reflective Review of Disruptive Innovation Theory. International Journal of Management Reviews, 12, 435-452. DOI: 10.1111/j.14682370.2009.00272.x

Zervas, G., Proserpio, D. \& Byers, J.W. (2017). The Rise of the Sharing Economy: Estimating the Impact of Airbnb on the Hotel Industry. Journal of Marketing Research, 54(5), 687-705. DOI.org/10.1509/jmr.15.0204

Zillinger, M., Jonasson, M. \& Adolfsson, P. (2012). Guided Tours and Tourism. Scandinavian Journal of Hospitality and Tourism, 12(1), 1-7. DOI:10.1080/15022250.2012.660314 
Summary of the questionnaire conducted among tourist guides (\%)

\begin{tabular}{|c|c|c|c|c|c|c|c|c|c|c|}
\hline & \multirow[b]{2}{*}{$\begin{array}{l}\text { Lea } \\
\text { flets }\end{array}$} & \multirow[b]{2}{*}{$\begin{array}{c}\text { Social } \\
\text { networ } \\
\text { ks }\end{array}$} & \multicolumn{3}{|c|}{ Websites } & \multicolumn{3}{|c|}{ Combined formulas } & \multirow[b]{2}{*}{$\begin{array}{c}\text { Nothi } \\
\text { ng }\end{array}$} & \multirow[b]{2}{*}{$\begin{array}{c}\text { Overall } \\
\text { total }\end{array}$} \\
\hline & & & $\begin{array}{c}\text { Platfo } \\
\text { rm } \\
\text { free } \\
\text { tour }\end{array}$ & $\begin{array}{l}\text { Institu } \\
\text { tional }\end{array}$ & Own & $\begin{array}{l}\text { Web } \\
\text { site+ } \\
\text { Leaf } \\
\text { lets }\end{array}$ & $\begin{array}{c}\text { Website + } \\
\text { Social } \\
\text { networks }\end{array}$ & $\begin{array}{c}\text { Website + } \\
\text { Leaflets + } \\
\text { Social } \\
\text { networks }\end{array}$ & & \\
\hline Works only for free tour platform & & & 1.9 & & & & & 3.8 & & 5.8 \\
\hline $\begin{array}{l}\text { Local guide hired by municipal } \\
\text { bodies (self-employed) }\end{array}$ & & 9.6 & & 1.9 & 1.9 & 1.9 & 9.6 & 1.9 & 5.8 & 32.7 \\
\hline Owner of own business & & 1.9 & & & 11.5 & & 7.7 & 13.5 & 1.9 & 34.6 \\
\hline Works for another company & 1.9 & 1.9 & & 1.9 & 1.9 & & & 7.7 & & 26.9 \\
\hline Overall total & 1.9 & 13.5 & 1.9 & 3.8 & 15.4 & 1.9 & 17.3 & 26.9 & & 100.0 \\
\hline
\end{tabular}

Source: Own elaboration based on the data of the survey 
Controversial elements with respect to the practice of free tours (\%)

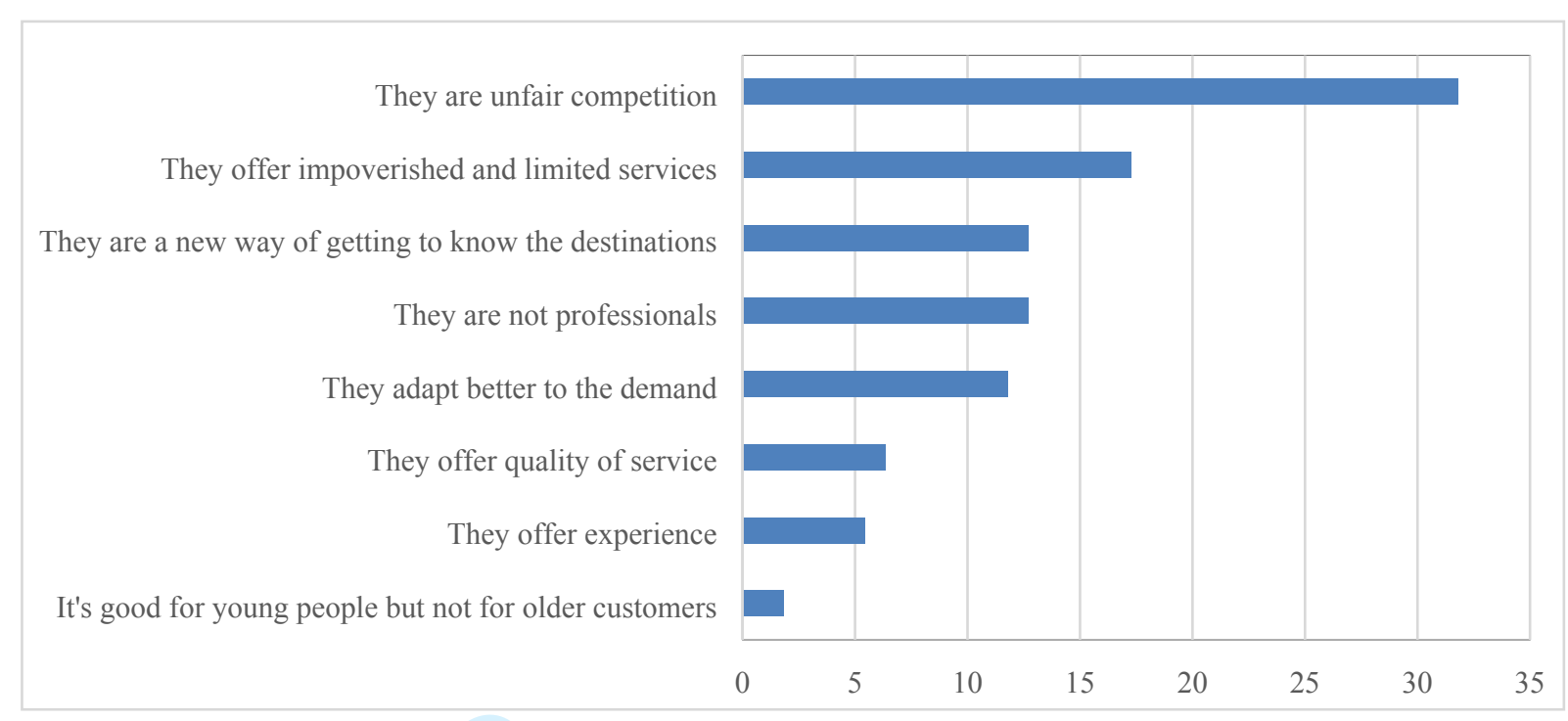

Source: Own elaboration based on the data of the survey 
Perception of the relationship between traditional and free tours (\%)

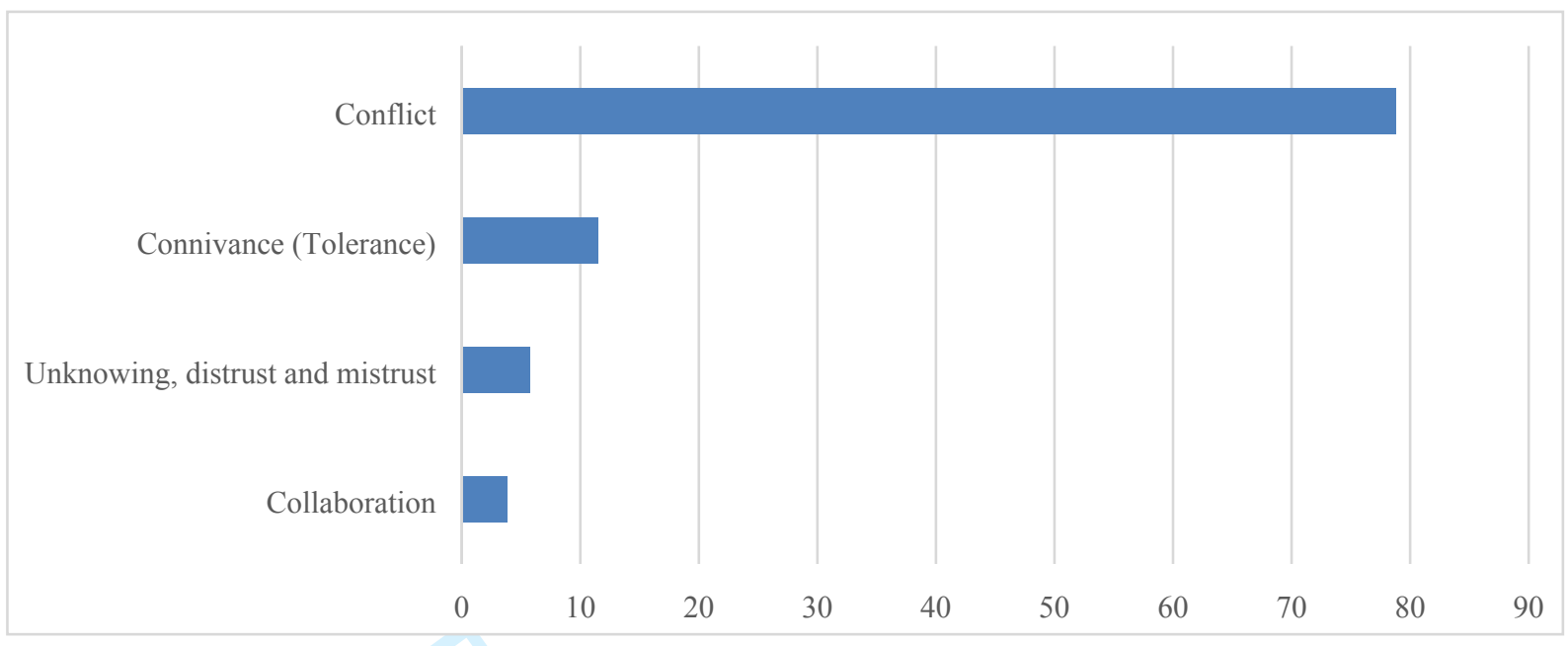

Source: Own elaboration based on the data of the survey 